The International Journal Of Engineering And Science (IJES)

|| Volume || 5 || Issue || 11 || Pages || PP 22-28 || 2016 ||

ISSN (e): $2319-1813$ ISSN (p): $2319-1805$

\title{
Community Participation in Health Care at Kendari City Public Hospital and Santa Anna Hospital Kendari
}

\author{
Rola Pola Anto ${ }^{1}$, Wempy Banga ${ }^{2}$, Jamal Bake ${ }^{3}$, Muh. Amir $^{4}$ \\ ${ }^{1}$ Doctoral Program of Management Science, Halu Oleo University Kendari Southeast Sulawesi, Indonesia \\ ${ }^{2,3,4}$ Faculty of Adiministration Science. Halu Oleo University, Southeast Sulawesi, Indonesia
}

\begin{abstract}
-
The purpose of this study was to determine and analyze the level of community participation in health care at Kendari City Public hospitals and Santa Anna Hospital Kendari City. Collecting data used in-depth interview, study of documents, observation and focus groups discussions (FGD). The results showed that community participation in health care at Kendari City Public hospitals and Santa Anna Hospital Kendari City in general has not been optimal. This is because the hospitals less to include the community to participate from the level of informing, consultation, placation, partnership, delegated power, and citizen control.
\end{abstract}

Keywords: community participation, health care, and hospitals.

Date of Submission: 29 October $2016 \longrightarrow$ Date of Accepted: 22 November 2016

\section{INTRODUCTION}

Community Participation is one of the consequences of the democratic government system as an option in the administration of state or government to implement development policies from the central level to the regions. The public has the freedom to participate by giving suggestions, ideas and criticism and complaints that are directly in contact with the public interest in the institutions of government and private institutions, including community participation in health care at Kendari City Public hospitals and Santa Anna Hospital Kendari City. Stipulated by the Law of the Republic of Indonesia Number 25/2009 on public service and Government Regulation No. 96 Year 2012 on the implementation of the public service, there is a mandate that in carrying out the public service should include the community as an important element in support of government policies, including the health services for the creation service fair, transparent, accountable and democratic. Various empirical facts Community Participation as research conducted Kenny et.al (2013) that the community participation in health services in rural research conducted at six locations in the USA, Canada, UK, Europe, Asia and Australia showed that the level of community participation most namely the high level of power to the citizens (represented) in accordance idea Arnstein. Studies of Abiona and Bello (2013) conducted a study in Nigeria found that grass-roots participation plays an important role in the development programs and decisionmaking processes in community development programs. Studies Kamuzora et al (2013) in Tanzania Mbarali highlighting how community participation will be encouraged in the context of resource poor, weak organization, and the fragility of democratic institutions. Health services in Kendari City Public hospitals and Santa Anna Hospital Kendari City not yet optimally engage with the communities, so that the participation of communities at the level of informing, consultation, placation, partnership, delegated power, and citizen control less than optimal. The problem of this research is how the level of community participation in health care at Kendari City Public hospitals and Santa Anna Hospital Kendari City. The purpose of this study was to determine and analyze the level of participation in the health services in Kendari City Public hospitals and Santa Anna Hospital Kendari City.

\section{LITERATURE REVIEW}

The application of democratic government was automatically the community can participate in many ways. Therefore, Abers (2000) stated that Community Participation is not just a matter of public responsibility to convey civic groups but also about increasing state control over the citizens. The concept of participation by Peter Bachrach (1967) in Varma (2001) that the active participation of individuals, which means decisions together, both coming from the participation of government and private organizations, in the broadest sense, is a major factor in developing the capabilities of the people. According to Pateman (1970) in Smith (2009) that the main function of participation in participatory democratic theory is as education, educating in a very broad sense. 
Theoretically the level of participation by Arnstein (1969) divided Eights rungs on the Ladder of Participation as follows: (1) manipulation (2) therapy, (3) informing, (4) consultation (5) placation, (6) partnership, ( 7) delegated power and (8) citizen control, level of community participation can be seen in Figure as follows:

Participation by Steve et al (1994) in Supriyatno (2009) that the participation of a given society can shape ideas, funds, manpower, and other forms that are useful. Theoretically Plummer and Taylor (2004: 56) points out the factors that influence people's participation are the internal factors of the community and individuals such as the role of the organization, gender, education, skills and knowledge, willingness to participate and external factors such as an organic law and the law, governance, policy leadership, administrative factors, the administrative structure, administrative relations, administrative responsibility, and administrative functions.

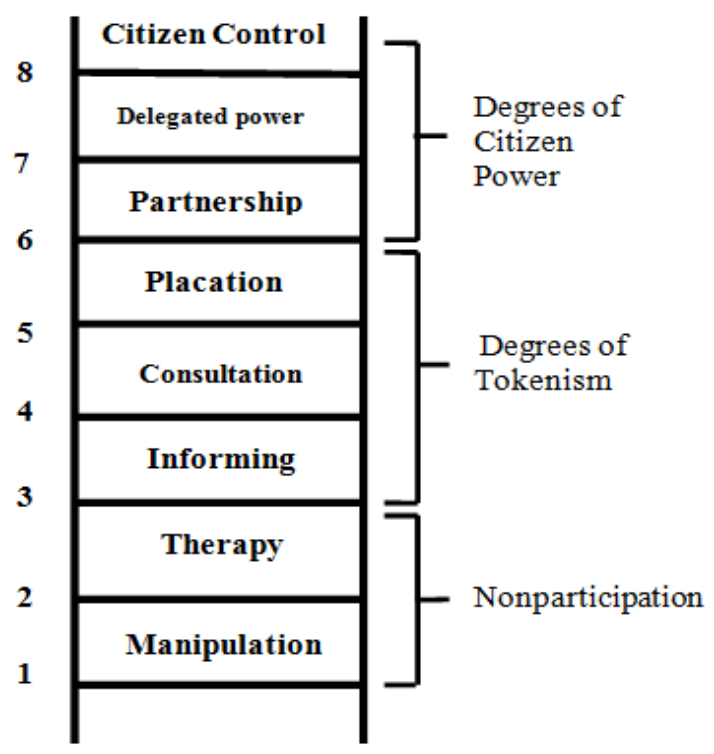

Eights Rungs on a Ladder of Citizen Participation (Arnstein, 1969)

\section{METHODOLOGY}

This study used a qualitative approach. The research was conducted at Kendari City Public hospitals and Santa Anna Hospital Kendari City. This study used qualitative methods (Creswell (2009 and Silalahi 2009), arguing that the paradigm of qualitative research is constructed as a research strategy that usually emphasizes words rather than quantification in data collection and analysis, emphasizing the inductive approach to the relationship between theoretical research, but placing emphasis on the creation of the theory (participation of theory). the qualitative research as a process of investigation to understand the social problems based on the creation of a full picture (holistic) formed with the words, reported in detail the views informants and compiled in a data naturally.

Sugiyono (2012) method of qualitative research is a research method that is used to examine the condition of natural objects, where the researcher is a key instrument, data collection techniques done by triangulation (combined), data analysis is inductive, and qualitative research results further emphasize the significance rather than generalization.

The informants are community of users of the service who had been treated in hospitals, academia, Non Governmental Organization (NGO) Observer of health services, community organizations, and health professional organizations. The collection of data through observation, study documents, in-depth interviews and focused group's discussion (FGD). The research instrument used in this research is interview, field notes and the researchers themselves. Analysis of data using a model description and analysis of information interactive model (Miles and Huberman, 1992, and Silalahi, 2009).

\section{RESULT AND DISCUSSION}

Community participation in health services in Kendari City Public hospitals and Santa Anna Hospital Kendari City as hospitals belonging to the private sector, can be analyzed based on the level of Community Participation or use the health services that had been treated, institutions swdaya society observers health care, academia and professional organizations health. The level of community participation in health care at Kendari City Public hospitals and Santa Anna Hospital Kendari City can be described as follows: 


\section{Manipulation}

Health services at Kendari City Public hospitals and Santa Anna Hospital Kendari City service programs or types of services such as health care outpatient services, inpatient and emergency department. The hospital also provides some clinics, administration or registration service time, service time patient, the name of the specialist physician practices. In addition, in the hospital also provided facilities and infrastructure, medical and non-medical, for example provided with air conditioning, chairs, TV, suggestion boxes and space information and complaints (observation, February 2016).

Based on the facts revealed that the health service in Kendari City Public hospitals and Santa Anna Hospital Kendari City, abuse is occurring in service. Health services at the hospital is not in accordance with the provisions of service time is not timely, the health worker or doctor come not in accordance with the time of patient care. All health workers know there are services that do not correspond with the time tables but only pretend not to know about the incident. This is relevant to the informant opinion that: ... never outpatient treatment at the Kendari City Public hospitals Kendari City at Polyclinic Internal Medicine, 08.30 We waited start 10:20 hours doctors had come to provide services to patients who are waiting in waiting room (interview, February 2016). This phenomenon is in line with the opinion of informants in Santa Anna Hospital that: ...services at Polyclinic In mistimed so patients should wait no clear time (interview, March 2016).

These facts indicate no manipulation or misuse of health care both in Kendari City Public hospitals and Santa Anna Hospital Kendari City. The procedure remains unfulfilled intentionally health care medical personnel and the hospital management simply let. This phenomenon shows that users of health services at the Kendari City Public hospitals and Santa Anna Hospital Kendari City just as users of some kind of health care that has been provided in the hospital. This phenomenon, in the view of theoretical Arnstein (1969) is called manipulation, and entry nonparticipation category, meaning that management only create an atmosphere of service to influence the attitudes and behavior of health service users in order to take advantage of the program and the type of health care at hospitals that have been provided.

\section{Therapy}

Health services at the Kendari City Public Hospital of Kendari as a government-owned hospitals and Santa Anna Hospital Kendari as private hospitals have made health care programs that may be in accordance with the user's choice of her illness. eg service time services such as outpatient and inpatient, emergency room (ER) or services by type of disease in each clinic. The user's position on the level of health care therapy is as an object in a program of outpatient services and inpatient care at Kendari City Public hospitals and Santa Anna Hospital Kendari City. Health service users can only view and listen to instructions and announcements as therapy efforts of employees on duty at the clinic. This is in line with the opinion of the health service users who had been treated at the Kendari City Public Hospital of Kendari that: ... . polyclinic services Ear, Nose and Throat, not in accordance with the established service time, because the service is not timely, as the patient at that time could only be following the instructions of service (interview, March 2016).

These facts indicate that the health service users as mere objects of outpatient care program or clinic. In this position, users of health services in the hospital (polyclinic) just follow the directions and instructions of the officers in the clinic outpatient health services. Therefore, an employee at the clinic to make improvements or cure of services that are not in line with expectations and the health service users only hear the announcement. It accordance with the relevant theoretical view Arnstein (1969) referred to therapy and in the category or level Nonparticipation, so the position of health service users, must abide by the rules of service in the health service. At the level of therapy there was no difference in the behavior of users of health services at hospitals with Santa Anna Hospital Kendari city but the same as the object of health care programs at the hospital.

\section{Informing}

The community can participate in health care at Kendari City Public Hospital and Santa Annal Hospital Kendari city because there are weaknesses or deficiencies felt or seen by the user after visiting the hospital. Shortcomings and weaknesses that gives users a reason to inform the health service to deliver media suggestions or complaints through suggestion boxes, SMS, direct survey of personnel at the hospital or directly on the unit information and complaints. Goal suggestions, criticisms and complaints directed at health care in inpatient, outpatient and emergency room (ER) which is not in line with expectations. The fact revealed that in 2015 users of health services at the Kendari City PublicHospital of Kendari submit suggestions and complaints as many as 22 people and 80 people. While, users of health services in Santa Anna Hospital Kendari who submit suggestions and complaints as many as 296 people and 131 people. These data indicate that there are still many users of health services that are not satisfied in the health service so that users of health services to provide suggestions and complaints, with the goal of weaknesses and deficiencies in health services can be improved. 
Empirical evidence shows that the level of informing the public or health service users submit information on health care by giving suggestions, criticisms and complaints at Hospital management Kendari and Santa Ana Hospital Kendari about shortcomings and weaknesses in patient care. It corresponds to the fact that the Kendari City Public Hospital as a government-owned hospitals Kendari trying to provide better service, but user ratings the many drawbacks, although in health care financing using Government funding of Kendari as a consequence of the responsibility and obligation of the government to serve the public, This is in accordance with the public service model, theoretically according to Savas (1987) called the government vending. At the level of informing, public or service users in the health services in Kendari. Santa Anna Hospital Kendari can convey information such as suggestions, criticisms and complaints on the management Santa Annal Hospital Kendari because there are still shortcomings in Santa Annal Hospital Kendari in providing health services to the community. Health services provided do not meet the public expectation. Therefore, users are entitled to health care to criticize, and complain that there is no improvement of health services. This is relevant to the informant opinion that: ....... .. Santa Anna Hospital Kendari got a lot of suggestions and complaints from the public or health service users are not satisfied because of the old buildings that need repair or rehabilitation, patient service time not in accordance with the provisions, when a doctor visit to patient room is not timely, the room facilities are not good, and the service ethic of employees (interview, March 2016). Any shortcomings in the health services on Santa Annal Hospital Kendari for the health service uses its own funds (self service), in contrast to Kendari City Hospital in healthcare services using government funds. Therefore the public can participate in health care at hospitals and Santa Anna Hospital Kendari to inform weaknesses and deficiencies in health care at the hospital is not optimal. This fact is relevant to the opinion of Arnstein (1969) called informing. Inform is the right of people to participate in the improvement of health services by giving suggestions, criticisms or complaints. At the level of informing is not optimal because there are many elements of society that have not inform regarding health care for example, from non-governmental organizations, academics, and health professional organizations.

\section{Consultation}

The fact revealed the level of community participation in health services in Kendari City PublicHospital and Santa Annal Hospital Kendari city on level consultation can be done through consultation or discussion on a reciprocal basis, between users of health services, non-governmental organizations (NGO) observers of health services and the organization of health professions to provide suggestions, criticism or complaints directly to the management of Kendari City PublicHospital and Santa Anna Hospital Kendari city, suggestions, criticism or complaint is heard, but the decision to be accepted or not accepted is in the hands of hospital management.

Empirically participation in Kendari City PublicHospital Kendari city at the level of consultation as Community Participation is not optimal, because the more dominant consultation is a health professional organizations and non-governmental organizations NGOs concerned health care, health care improvement agenda to discuss appropriate suggestions and complaints from the public. While community participation in health services in Kendari Santa Anna Hospital at the level of consultation, only professional organization that consults with management to discuss the appropriate service improvement suggestions, criticisms and complaints. Consultation is a process of exchange of thoughts or dialogue directly with management Hospital of Kendari and the Santa Anna Hospital Kendari to express their opinions and ideas related to health care in hospitals, but any conclusions or final decision is on the hospital management in theoretical view Arstein (1969 ) referred to the consultation.

\section{Placation}

Community participation in health care at the Kendari City PublicHospital Kendari placation level, ie, all suggestions, criticism or complaints from the public or service users who had been treated, Non Governmental Organization (NGO) observer health services and health professional organizations housed by the hospital management Kendari. It is relevant to the informant opinion that: ... .. professional organization of Indonesian National Nurses Association (INNA) Branch of Kendari often send suggestions or opinions on the management of hospital associated with good services, training for nurses and repair fees for nurses as family labor sick but advice and opinions that only accommodated (interview, March 2016). The management only promised to make improvements, but the fact cannot be repaired, the promise is just a promise. For example: air conditioning in the room outpatient damaged, indoor heat always promised to be repaired but the fact is not repaired. This is done only to reduce anger management people, so the stairs placation participation in the category of tokenism (sign).

Empirical evidence shows that community participation in health care at the level of placation Santa Anna Hospital Kendari, the hospital management only accommodates suggestions and criticism or complaints from service users who had been treated and health professional organizations. All suggestions and criticisms 
accommodated and management promised to make improvements in accordance suggestions and complaints. But in fact the management is still to carry out services without corresponding improvement suggestions and complaints from the public Thus, at the level of community participation in health care placation at City Hospital and Santa Anna Hospital Kendari been there, and the management promised to make improvements but the fact has not made significant improvements. So the hospital management only dampens public anger, health-care program implemented although there has been criticism and suggestions. The facts are relevant to the opinion of Arnstein (1969) by calling placation and into the category of tokenism.

\section{Partnership}

The facts are revealed in this paper that the community participation in health services in Kendari City Public hospitals Kendari can be realized through the cooperation between the health professional organizations and non-governmental organizations (NGO) observers of health care with Kendari City Public hospitals Kendari, it is relevant informant opinion that: ... .. Aisha organizations partnering with hospitals Kendari in health care, especially prevention of Tuberculosis disease in the city of Kendari. The partnership was evidenced by the MoU signed between the board Aisha with Hospital Director of Kendari (Interview, March 2016). It is relevant to the informant opinion that: ... . Indonesian MedicalAssociation (IMA) premises partnership with the city of Kendari in terms of providing recommendations for a prospective employee who is a doctor, and give advice on hospital accreditation (interview, March 2016).

These facts indicate that the public in this case non-governmental organizations, organizations and healthcare professionals can participate in the health services in Kendari City Public hospitals Kendari by cooperating. While in the Santa Anna hospital Kendari, community can participate at the level of partnership only professional organization of health and non-governmental organizations At the level of partnership society got the same position or be treated like colleagues by hospital management in making program planning or health care policy at hospitals Kendari and the Santa Anna hospital Kendari. So people participating in health services by way of a partnership, it is relevant to the theoretical view Arnstein (1969) called the partnership with the category of citizen power.

\section{Delegated Power}

Empirically community participation in health services in Kendari City Public hospitals Kendari, found their delegation of authority for planning and decision making. This is relevant to the opinion of informants stated that: ... as a members of the Indonesian Doctors Association of Kendari often gets authority from management to participate in determining the best plan in the health service hospitals Kendari. For example, making patient care standards refer to the existing regulations, determine medical devices eligible for services provided to patients (interview, March 2016). The presence of the delegation of authority in a professional organization until the decision in view of theoretical Arnstein (1969) called the power delegated to the category of citizen power. Theoretically delegated power is that people can participate for their distribution or greater delegation of authority from the management of the hospital to the community to make decisions with respect to the improvement of health services in Kendari City Public hospitals Kendari. This is relevant to the opinion that the participation as a process in which individuals, groups and organizations choose to take an active role in decisions that affect them (Reed, 2008).

Community participation in health services in Santa Anna Hospital Kendari can be done by participating in the planning and decision-making procedures of the service according to their profession as the profession of medicine, midwifery profession and the nursing profession. It correspond opinion of one informant who stated that: ... health professions Indonesian Medical Association (IMA) received a delegation of authority from the hospital management to assist in planning and decision-making in the improvement of health services in Santa Anna Hospital Kendari (interview, March 2016). Community participation is in line with the opinion of Arnstein (1969) called the Delegated Power, with the category of Citizen Power. Based on these facts, the Community Participation at the level of Delegated Power is not optimal.

\section{Citizen Control}

The facts are revealed in this study, that the community participation in health services in Kendari City Public hospitals can be done by means of control over all activities of the health service. Community or to exercise control because as a government-owned hospitals then all the financing facilities, arrangements and salaries, and the provision of hospital facilities using government funds, so normal in health care must involve the public. Controls can be derived from the user community health services, academia, non-governmental organizations (NGOs) and health professional organizations. This is in accordance with the opinion of one informant who stated that: ... . Indonesian MedicalAssociation (IMA) Kendari perform controls on doctors working at the hospital. In addition, Indonesian MedicalAssociation (IMA) of Kendari also conduct special controls at Kendari City Public hospitals Kendari City, doctors in providing services at the clinic and inpatient 
services (interview, March 2016). These facts indicate that the Kendari City Public hospitals Kendari as a hospital belonging to the City of Kendari, has to include the community to exercise control in health care but not yet optimal, in the view of theoretical Arnstein (1969) called citizen control, with the category of citizen power. This is done to make health care that is fair, transparent, accountable and democratic. This fact is relevant to the opinion of Abe (2005) and Sugandi (2011) that involve people directly would bring significant impact, namely: (1) avoid the possibility of manipulation. Community involvement will clarify what is actually desired by the community; (2) provide added value in the formulation of the legitimacy of the planning because the more the number of people involved, the better; and (3) improving public awareness and political involvement.

Community participation at the level of citizen control in health care in Santa Anna Hospital Kendari only limited to the control of ambulatory care and inpatient facilities, the hospital environment and hospital staff. This is in accordance with the opinion of informants stated that: ... .community not involved in the control of the planning and decision making directly for the right to take the decision to make improvements is authorized hospital management without involving the public openly, considering Santa Anna Hospital Kendari as private hospitals has its own authority (interview, March 2016). Community participation at the level of citizen control community has the responsibility and authority to provide control in health care for the progress of the hospital, the achievement of better service quality. The purpose of community participation in health care is to create a service that is fair, transparent, accountable and democratic. The fact revealed indicates the public authority to exercise control in health care in hospitals, in the view of theoretical Arnstein (1969) called citizen control. Community control in health care in Kendari City PublicHospital and Santa Anna Hospital Kendari City is part of a public authority or category of citizen power (Arnstein, 1969). Based on these descriptions, the community participation in health services at the Kendari City PublicHospital and Santa Anna Hospital Kendari has reached the level of citizen power or the public just not optimal.

Based on the facts are revealed, then the community participation in health care at Kendari City Public Hospital and Santa Anna Hospital Kendari generally not optimal from the level of informing, consultation, placation, partnership, delegated power, and citizen control. There are differences in groups of people who can participate in the public health service, namely in Kendari City Public Hospital Kendari to participate is a health service users ever cared, NGO observer health services, academic and health professional organizations. In Santa Anna Hospital Kendari to participate the health service users who had been treated, academics, and health professional organizations, while non-governmental organizations are not able to participate at every level of participation for the management Santa Anna Hospital Kendari not cooperating in health care

\section{CONCLUSION AND RECOMENDATION}

Based on the results of research and discussion it can be concluded that: (1) the level of community participation in health services in Kendari City Public Hospital starting from the level of informing, consultation, placation, partnership, delegated power, and citizen control and (2) the level of community participation in health care on Santa Anna Hospital Kendari starting from the level of informing, consultation, placation, partnership and delegated power. People who can participate in the health service in Kendari City Public Hospital is a health service users who had been treated, academics, and health professional organizations and non-governmental organizations (NGO) observer health services. While the public to participate in the health service in Santa Anna Hospital Kendari namely health service users who had been treated and health professional organizations. Especially for observer NGO health services and academia have not participated in the health service in Santa Anna Hospital Kendari. Community participation at Kendari City Public Hospital and Santa Anna Hospital Kendari Kendari is an implementation of democratic values in a democratic country that always gives space for people to express thoughts, suggestions, criticisms or complaints freely for the realization of health care that is fair, accountable and transparent and democratic.

The study of community participation in health services at hospitals require sufficient time to explore the community can participate. Therefore, future required further research to find out more details about the level of Community Participation in government hospitals and hospitals owned by private forms of civic participation and the factors that influence community participation, particularly in developing countries in this world.

\section{REFERENCES}

[1]. Abe, Alexander. 2005. Participatory Planning. Yogyakarta: Pustaka Jogja Mandiri.

[2]. Abers, Rebecca Neaera, 2000, Inventing Local Democracy, Lynne Rienner Publishers, United States of America

[3]. Abiona, Adekeye dan Bello, W. Niyi, 2013, Grassroots Participation in Decision-Making Process and Development Programmes as Correlate of Sustainability of Community Development Programmes in Nigeria, Journal of Sustainable Development; Vol. 6, No. 3; 2013 ISSN 1913-9063 E-ISSN 1913-9071 Published by Canadian Center of Science and Education.

[4]. Alam, Khorshed., 2013, Factors Affecting Community Participation In River Ecosystem Restoration: Using The Contingent Valuation Method, The Journal of Developing Areas Volume 47 No. 1 Spring 2013

[5]. Arnstein, Sherry R., 1969, A Ladder Citizen Participation, AIP Journal, USA 
[6]. Central Bureau of Statistics, 2015, City of Kendari

[7]. Creswell, John W., 2009, Research Design: Qualitative, quantitative and mixed methods approaches, Thid Edition, Sage Publications, thousand Oaks California

[8]. Culley, Marci R. and Hughey, Joseph, Power and Community Participation in a Hazardous Waste Dispute: A Community Case Study.Am J Community Psychol (2008) 41:99-114 DOI 10.1007/s10464-007-9157-5

[9]. Dudley, Eric., 2002, The Critical Villager Beyond community participation, Lane, London EC4P 4EE This edition published in the Taylor \& Francis e-Library, 2002.

[10]. Idris, Usman Abba, 2013, Levels Of Farmers' Participation In Sudan Savanna Challenge Programme In Bunkure Local Government Area Of Kano State, European Scientific Journal September 2013 Edition Vol.9, No.26. pp. 280-288, ISSN: 1857 7881 (Print) E - ISSN 1857- 7431 280, Department Of Adult Education And Community Services, Bayero University, Kano

[11]. Kamuzora, Peter, Stephen Maluka, Benedict Ndawi, Jens Byskov And Anna-Karin Hurtig, 2013, Promoting Community Participation In Priority Setting In District Health Systems: Experiences From Mbarali District, Tanzania, Citation: Glob Health Action 2013, pp. 1-12, 6: 22669

[12]. Kenny, Amanda, Nerida Hyett, John Sawtell, Virginia Dickson-Swift, Jane Farmer and Peter O'Meara, 2013, Community Participation In Rural Health: A Scoping Review BMC Health Services Research 2013, 13:64 http://www.biomedcentral.com/14726963/13/64. PP. $1-8$

[13]. Nathan, Sally, Jeffrey Braithwaite and Niamh Stephenson, 2013, Facilitating the action of community representatives in a health service: the role of a community participation coordinator, BMC Health Services Research 2013, 13:154, http://www.biomedcentral.com/1472-6963/13/154, PP.1-12.

[14]. Plummer, Janelle and Taylor, John G (editor), 2004, Community Participation in ChinaI:ssues and Processes for Capacity Building, First published by Earthscan in the UK and USA.

[15]. Rajendran, K., 2012, Level Of Participation Of Rural Women In Micro Insurance: Evidences From The Field, July 2012/ Volume 2/Issue 7/Article No-13/1237-1247

[16]. Reed, M.S. 2008. Stakeholder Participation For Environmental Management: A Literature Review. Biological Conservation 141: 2417-2431

[17]. Savas, E.S, (1987), Privatization: The Key to Better Government (New Jersey: Chatham House Publishers.

[18]. Savas, E.S. (1997). Privatization and Public Partnerships. LLC, New York - London: Chatham House Publishers, Seven Bridges Press

[19]. Silalahi, Ulber, 2009, Social Research Methods, Refika Aditama, Bandung

[20]. Smith, Graham, 2009, Innovations Democracy: Designing institutions for citizen participation, Published in the United States of America by Cambridge University Press, New York.

[21]. Sugandi, Yogi Supriyadi, 2011, Public Administration: Concepts and Development Studies in Indonesia, Graha Ilmu, Yogyakarta.

[22]. Sugiyono, 2012. Qualitative and Quantitative Research Methods. Alfabeta, Bandung.

[23]. Sugiyono, 2010, Understanding Of Qualitative Research, Alfabeta, Bandung

[24]. Supriyanto, Budi, 2009, the Government Management: Strategic Plus Twelve Steps, Brilliant Media, Jakarta

[25]. Law of the Republic of Indonesia Number 25 Year 2009 Regarding Public Service

[26]. The Indonesian Government Regulation Number 96 Year 2012 on The Implementation of The Public Service.

[27]. Varma, S.P, 2001, Modern Political Theory, Grafindo Persada, Jakarta 